\title{
A PEDAGOGIA NO ESPAÇO CIBERNÉTICO: A DINÂMICA DO DISCURSO ONLINE ${ }^{1}$
}

\author{
Cindy $\mathrm{Xin}^{2}$ \\ Andrew Feenberg ${ }^{3}$ \\ Tradutor: Fabrício Klain Cristofoletti (UVA), fabricioklain@gmail.com
}

Resumo:

$\mathrm{O}$ artigo elabora um modelo para a compreensão da pedagogia no ambiente dos fóruns educacionais online. $\mathrm{O}$ modelo identifica quatro componentes. Primeiro, o engajamento intelectual é o componente que revela os processos cognitivos de primeiro plano do aprendizado colaborativo. Em segundo lugar, os processos de comunicação que operam no plano de fundo são aqueles que acumulam um depósito ainda mais rico de conhecimentos compartilhados que possibilitam o avanço da conversação. Em terceiro lugar, o processo colaborativo é o componente que requer um moderador para coordenar a comunicação e o aprendizado em grupo. O moderador na educação online é geralmente um professor que compartilha o conhecimento no processo de liderar a discussão. Em quarto e último lugar, a discussão bem-sucedida gera motivações intrínsecas para a participação, as quais mantêm a discussão em andamento. Tal estrutura foi projetada para mostrar a complexidade da discussão online e fornecer uma base que sirva para orientar professores e avaliar aplicativos e softwares.

Palavras-chave: Discurso online. Espaço cibernético. Pedagogia.

\section{PEDAGOGY IN CYBERSPACE: THE DYNAMICS OF ONLINE DISCOURSE}

\begin{abstract}
:
This article elaborates a model for understanding pedagogy in online educational forums. The model identifies four key components. Intellectual engagement describes the foreground cognitive processes of collaborative learning. Communication processes operating in the background accumulate an ever richer store of shared understandings that enable the forward movement of the conversation. The collaborative process requires a moderator to coordinate communication and learning in a group. The moderator in online education is usually a teacher who shares knowledge in the process of leading discussion. Finally, a successful discussion generates intrinsic motivations to participate, which keep the discussion going. This framework is designed to bring out the complexity of online discussion and to provide a basis for advising teachers and evaluating applications and software.
\end{abstract}

Keywords: Online Discourse. Cyberspace. Pedagogy.

1 Nota do Tradutor (N. do T.): o artigo foi originalmente publicado no periódico Journal of Distance Education / Revue de l'education à distance, Canadá, vol. 21, n. 2, pp. 1-25, outono de 2006. Disponível em: http://www.ijede.ca/index.php/jde/article/view/60/842. Acesso em: 30/04/2020. Os autores e editores da publicação original concederam permissão para a tradução por meio de correspondência eletrônica. O tradutor lhes agradece a autorização para a tradução e publicação deste artigo em língua portuguesa.

2 Doutora e Professora na Simon Fraser University. Conduziu pesquisas e desenvolvimentos na área de aprendizado online e trabalhou para a rede de ensino a distância de centros de excelência e para o Departamento de Educação dos Estados Unidos da América. É membro de uma equipe que desenvolve tecnologias de código aberto para a melhoria dos fóruns de discussão online. Contato: cxin@sfu.ca.

3 Doutor e Professor na Escola de Comunicação da Simon Fraser University, onde ocupa a Cátedra de Pesquisa em Filosofia da Tecnologia. É reconhecido como um inovador pioneiro no campo da Educação Online. Foi membro de uma equipe que criou o primeiro programa de educação online em 1982 no Western Behavioral Sciences Institute, em La Jolla, Califórnia. Realizou pesquisas sobre educação online e comunidade online para o Departamento de Educação dos E.U.A. e para a National Science Foundation. Contato: feenberg@sfu.ca. 


\section{A PEDAGOGIA NO ESPACO CIBERNÉTICO: A DINÂMICA...}

Cindy Xin / Andrew Feenberg

\section{Introdução}

Nesta introdução, caracterizamos o problema da Pedagogia Online em termos de um ideal de discussão efetiva, a qual chamamos de "discurso colaborativo engajado". Também expomos, nesta seção, a metodologia empregada neste artigo.

\section{O contexto e o propósito deste estudo}

A maioria das novas ferramentas e práticas empregadas na educação online são versões que medeiam eletronicamente técnicas pedagógicas conhecidas. Isso é inteiramente verdadeiro para a discussão online nos fóruns de internet assíncronos. Porém, há diferenças significativas entre as formas escritas e as orais do discurso colaborativo engajado. O primeiro propósito deste artigo é explicar as implicações dessas diferenças para a pedagogia no espaço cibernético.

Como principal forma de interação humana por meio de computadores na educação online, a discussão desempenha um papel vital e ainda mais significativo para o aprendizado do que aquela que ocorre face a face em sala de aula. Os benefícios comumente identificados incluem discussões mais reflexivas e participação mais ampla. Os estudantes frequentemente se interessam mais por ler online do que alguém poderia imaginar a partir de suas contribuições em sala de aula, onde participantes lentos ou tímidos são ofuscados por colegas de trato mais fácil, mas nem sempre mais inteligentes. Professores também descobrem com frequência que são melhores quando lideram uma discussão escrita tendo tempo para refletir sobre as ideias dos estudantes antes de preparar cuidadosamente as respostas.

Mas gerenciar a discussão online é um pouco mais difícil e demorado do que se poderia supor com base numa simples analogia com a sala de aula. A discussão online é paradoxal. Ela consiste num fluxo de trocas improvisadas relativamente desorganizadas que, de algum modo, alcançam agendas de curso altamente ambiciosas e racionalizadas. Apesar da incoerência aparente da conversa online, participantes têm estabelecido normas que retomam a coerência e o caráter pessoal da interação conversacional (HERRING, 1996, 1999). Um modelo conceitual desse fenômeno deve levar em conta ambos os aspectos - o aparente caos e a ordem - ou então deve mostrar como o primeiro é de fato um aspecto do outro enquanto processo de construção de conhecimento que combina a lógica informal da conversação com a racionalidade formal do discurso acadêmico. O segundo propósito deste artigo é, portanto,

\begin{tabular}{|c|c|c|c|c|}
\hline Rovista Dialectus & Ano 9 & n. 17 & Maio - Agosto 2020 & p.182-211 \\
\hline
\end{tabular}




\section{A PEDAGOGIA NO ESPACO CIBERNÉTICO: A DINÂMICA...}

Cindy Xin / Andrew Feenberg

explicar a discussão online em toda a sua complexidade, sem simplificá-la para dela fazer um padrão mais coerente do que ela exige de fato.

As questões pedagógicas que exploramos estão situadas num contexto mais amplo. A interação humana na educação online tem sido subestimada e subvalorizada pelos maiores atores comerciais na área (HAMILTON; FEENBERG, 2005). Uma década de experiência com sistemas de gestão de aprendizado, projetados originalmente como mostruários de ferramentas para cursos, de marcas registradas, vendáveis, deixou muitos educadores céticos quanto ao valor da educação online. Produtos como WebCT e Blackboard realmente incluem fóruns de internet, mas não se tem dado muita atenção a seus projetos e menos ainda à capacidade de treinamento para usá-los efetivamente. Talvez um melhor entendimento da dinâmica do aprendizado em fóruns assíncronos possa contribuir para a superação desse viés e reconcentrar esforços na educação online a partir da relação entre professores e alunos.

\section{A complexidade da discussão online}

Com a expressão "discurso colaborativo engajado", significamos um diálogo em grupo em busca de entendimento e convergência compartilhados. O termo "engajado" é usado aqui para enfatizar que os participantes interagem uns com os outros em torno de questões substanciais. Em nossa visão, o discurso colaborativo engajado é a melhor das possíveis utilizações dos fóruns online para propósitos educacionais. Ele deveria desempenhar um papel significativo tanto no aprendizado a distância como no semipresencial. Todavia, não afirmamos que tal discurso seja a prática típica ou padrão dos educadores e estudantes online. Trata-se de um desafio e de uma atividade trabalhosa para professores e alunos, mas que vale a pena.

Como sua contraparte face a face, a discussão online combina perfeitamente muitos atos de fala em cada enunciado. Por exemplo, reconhecer o recebimento de uma mensagem carrega ao menos dois tipos de informação que estão atrás do seu escritor: a informação sobre o processo material da comunicação (a mensagem foi para frente) e a informação sobre as relações humanas da comunicação (alguém notou a mensagem e a julgou aceitável). Se a troca é semanticamente rica o suficiente, informações correlacionadas ao conteúdo podem também ser transmitidas por meio da resposta, avançando assim o processo comunicativo em que os interlocutores estão engajados. Essas interações possuem uma significação dinâmica

\begin{tabular}{|l|l|l|l|l|}
\hline Govista Qialectus & Ano 9 & n. 17 & Maio - Agosto 2020 & p.182-211 \\
\hline
\end{tabular}




\section{A PEDAGOGIA NO ESPACO CIBERNÉTICO: A DINÂMICA...}

Cindy Xin / Andrew Feenberg

maior: escrever uma mensagem que venha a ser entregue e aceita encoraja novas atividades no fórum. Tais condensações das funções discursivas não são exceção à regra; pelo contrário, são típicas da complexidade em múltiplas camadas da comunicação humana.

Na educação, a complexidade possui uma camada adicional geralmente encontrada em outros contextos, a saber, a construção de conhecimento por meio da troca intelectual na comunidade pedagógica. As relações sociais da comunicação estão entrelaçadas com o processo de aprendizado em caminhos que, embora difíceis de analisar, são compreendidos intuitivamente, em algum grau, por professores e estudantes que recorreram à experiência educacional durante toda a vida.

A literatura educacional não reflete sempre esse entrelaçamento da comunicação humana. Grande parte do trabalho existente classifica as várias ações comunicativas dentro de uma ou outra categoria, a depender do intérprete, se este enfoca aspectos sociais, ou de instrução ou de cognição do discurso. De fato, os enunciados frequentemente servem a múltiplos propósitos, os quais podem ser distintos analiticamente. Identificamos quatro dessas camadas de interação comunicativa na discussão online. Elas são (a) o engajamento intelectual, (b) a comunicação e a base comum, (c) o diálogo e a motivação e (d) a dinâmica de grupo e a liderança. Distinções analíticas, como essas que fazemos aqui, são de grande valor para entender a complexidade do fenômeno; porém, elas nem sempre correspondem a distinções claras na realidade. O importante é perceber a relação entre os múltiplos aspectos do mesmo fenômeno e ver claramente a interação entre todos eles.

Nas páginas seguintes, discutiremos as quatro camadas pedagogicamente significativas do discurso educacional online à luz de uma ampla variedade de estudos sobre vários aspectos da comunicação humana e do aprendizado. Nenhum desses estudos descreve exaustivamente todos os aspectos desse complexo objeto. Alguns aspectos têm recebido mais atenção do que outros, com uma decorrente exageração que esperamos aqui corrigir.

$O$ engajamento intelectual. $\mathrm{O}$ engajamento intelectual consiste em apresentar exemplos, elaborar argumentos, criticar visões, definir termos, aplicar conceitos e assim por diante. Essas realizações explícitas formam o que chamamos de "processo de primeiro plano". Ele pressupõe implicitamente conhecimentos de background previamente estabelecidos no processo de comunicação ou trazidos da herança cultural comum dos participantes. O processo de engajamento intelectual ultrapassa uma série de fases na medida em que os participantes em diálogo trabalham em direção a um entendimento compartilhado das

\begin{tabular}{|c|c|c|c|c|}
\hline Q Rovista Dialectus & Ano 9 & n. 17 & Maio - Agosto 2020 & p.182-211 \\
\hline
\end{tabular}




\section{A PEDAGOGIA NO ESPACO CIBERNÉTICO: A DINÂMICA...}

Cindy Xin / Andrew Feenberg

questões, quando não necessariamente ao acordo. O desenvolvimento progressivo das discussões online através de estágios logicamente conectados é estudado de modo mais completo na literatura sobre pensamento crítico do que naquela sobre outros aspectos da Pedagogia da Discussão, talvez porque nós temos ideias bem estabelecidas sobre a racionalidade que atraem o senso comum e especialmente os professores. Mas a visão convencional de racionalidade é cada vez mais contestada como excessivamente formalista em campos tão diversos como, por exemplo, o da Interação Homem-computador e o dos Estudos sobre a Ciência (LYNCH, 1993). Nós podemos, entretanto, apreender algo útil dessa literatura sobre o modo como professores e estudantes, confiando em suas próprias noções de racionalidade, trabalham em direção a fins que eles reconhecem como educacionalmente válidos.

A comunicação e a base comum. Esse é um aspecto não teorizado dos estudos sobre a educação online. Toda discussão, online ou face a face, deve proceder com base em suposições compartilhadas: uma base comum que serve, no plano de fundo, para o entendimento mútuo. Os conceitos, suposições e métodos de argumento operativo na discussão de primeiro plano são retiradas dessa base comum. No curso de uma discussão bem-sucedida, a base comum é continuamente alargada e seu alargamento verificado através de uma variedade de atos de fala estudados pela Análise da Conversação. Cada alargamento autoriza um avanço extra da agenda da discussão.

O diálogo e a motivação. Os fóruns de discussão online constituem diálogos escritos e compartilham características com o diálogo face a face. A pedagogia dialógica remonta, pelo menos, a Sócrates, que conduziu estudantes, através de questões apropriadas, a uma conclusão, e que a ela chegaram para si mesmos. Como um jogo com movimentos alternativos, a inquirição dialógica gera motivações intrínsecas para a participação. Essas incluem a surpresa, o suspense e a sensação de realização. Olhamos para essas motivações mais pela perspectiva do processo dialógico do que por aquela dos participantes individuais que se juntam, a partir de suas vidas offline, numa discussão online, por várias razões (p. ex., desejo de aprender, obtenção de créditos acadêmicos). Pouca atenção tem sido dada, na literatura específica, a essas motivações e à sua importância vital para a manutenção do diálogo.

A dinâmica em grupo e a liderança. A dinâmica de grupo prossegue através de estágios mais ou menos conhecidos de familiarização, de testagem da boa vontade dos

\begin{tabular}{|c|c|c|c|c|}
\hline Rovista Dialectus & Ano 9 & n. 17 & Maio - Agosto 2020 & p.182-211 \\
\hline
\end{tabular}




\section{A PEDAGOGIA NO ESPACO CIBERNÉTICO: A DINÂMICA...}

Cindy Xin / Andrew Feenberg

parceiros, de construção de familiaridade e de confiança, de vinculação de tarefas compartilhadas, experiências, crises. Esses aspectos sociológicos da discussão online têm sido exaustivamente discutidos na literatura existente $\mathrm{e}$ não os examinaremos aqui (GUNAWARDENA, 1995; GUNAWARDENA; ZITTLE, 1997; ROURKE, 2000; ROURKE, ANDERSON, GARRISON; ARCHER, 1999). Em vez disso, enfocamos a moderação, o papel da liderança geralmente assinalada ao professor, embora frequentemente compartilhado pelos participantes no campo da Pedagogia da Discussão. A dispersão dos participantes no espaço e no tempo e na ausência de pistas implícitas coloca problemas especiais que são resolvidos através da liderança ativa. O uso do termo "liderança" aqui não segue o sentido dado pela Psicologia Social, segundo a qual a liderança é geralmente relacionada à organização da gestão, mas, antes, refere-se ao processo de facilitar ou guiar o processo de aprendizado colaborativo através do diálogo. De fato, usamos os temos "liderança" e "moderação" de forma intercambiável. Portanto, liderar, no contexto deste artigo, consiste em iniciar e sustentar um diálogo e mediar o aprendizado dos estudantes através do uso de uma série de funções moderadoras que discutiremos a seguir.

A Figura 1 ilustra nosso modelo de discurso colaborativo engajado, o qual descreve as relações entre aquelas quatro camadas. Os dois processos básicos são o engajamento intelectual e a comunicação. A comunicação leva ao alargamento da base comum, representada no diagrama pelas ovais gradualmente alargadas. O engajamento intelectual leva à mudança conceitual para os indivíduos e à convergência gradual para o grupo. As funções moderadoras intermedeiam os dois. O suspense, a surpresa e a sensação de realização levam à absorção. Essas motivações intrínsecas para a participação, sustentada pelas funções moderadoras, estimulam a comunicação e o engajamento intelectual. As setas ligando os quatro componentes significam as relações entre eles. 


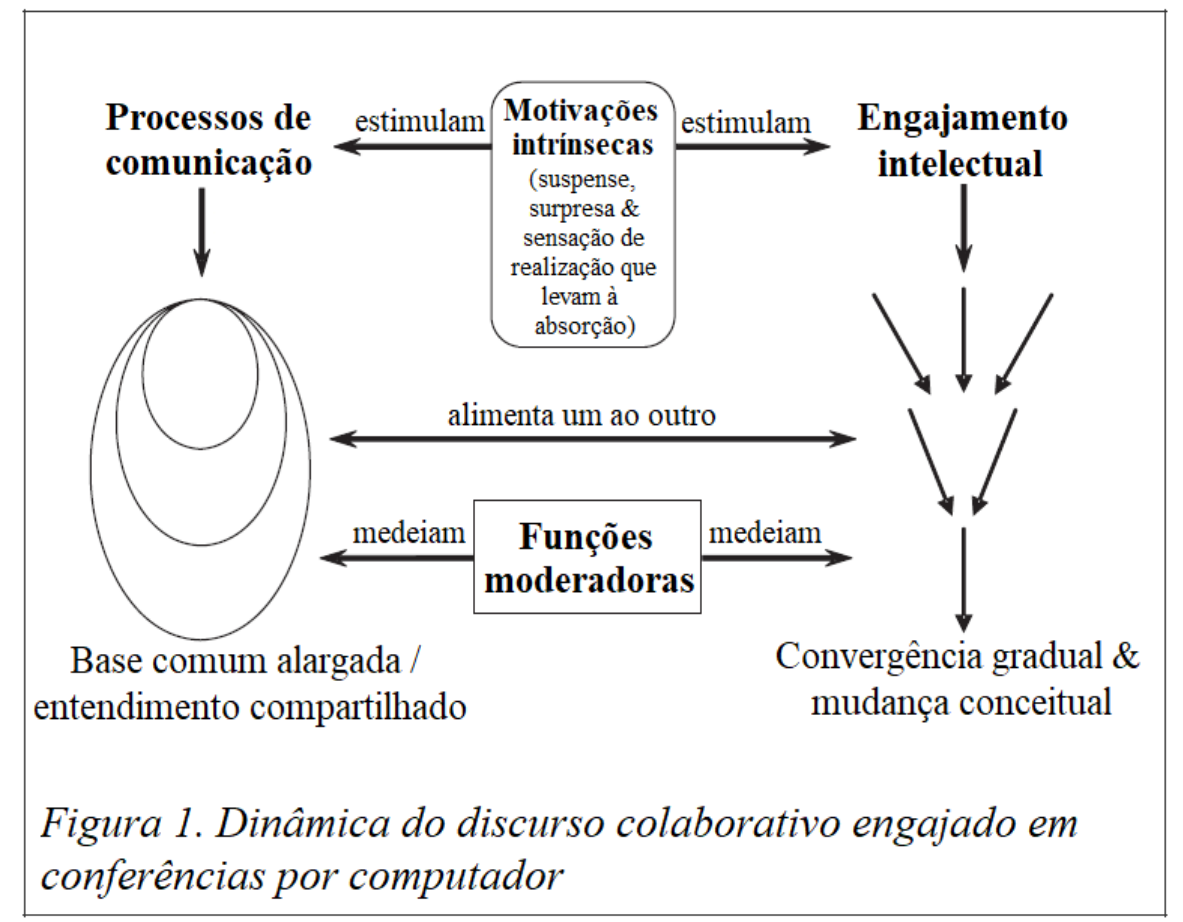

Abaixo, providenciamos análises aprofundadas de cada uma dessas camadas e 188 descrições da relação entre elas.

\section{Os aspectos cognitivos}

As três seções seguintes desenvolvem um modelo acerca dos processos cognitivos através dos quais os estudantes constroem o conhecimento disciplinar com base na interação entre si e com o professor.

\section{O engajamento intelectual}

Os objetivos do engajamento intelectual através do discurso colaborativo consistem em atingir a convergência no nível grupal e a mudança conceitual no nível individual. Esses dois resultados estão conectados: os membros individuais adquirem novos conceitos e atingem uma mudança conceitual por meio da construção conjunta e deliberada de conhecimento no grupo. Esse processo combinado abarca o nosso entendimento sobre o aprendizado desde Vygotsky (1962). Desenvolvimentos na Teoria da Cognição, na Teoria do

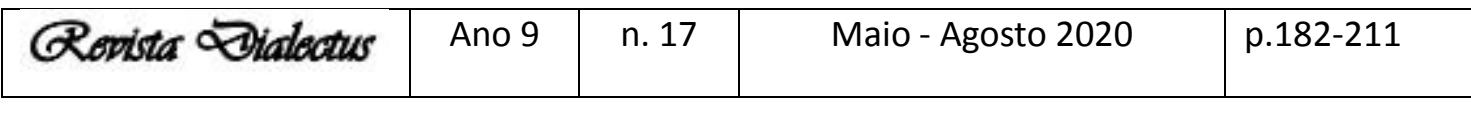




\section{A PEDAGOGIA NO ESPACO CIBERNÉTICO: A DINÂMICA...}

Cindy Xin / Andrew Feenberg

Aprendizado e na Filosofia da Ciência enfatizam cada vez mais a natureza social, cultural e distribuída da cognição (HUTCHINS, 1991, 1995; OATLEY, 1991; KITCHER, 1993; PEA, 1993).

Roschelle (1996) argumenta que a encruzilhada da colaboração é a luta pela convergência por meio da mudança conceitual. A convergência requer partilhar visões comuns e diferentes, negociar diferentes níveis de entendimento, visitar e revisitar horizontes diferentes, bem como a fusão gradual de tudo isso (GADAMER, 1982). Pesquisas em Análise da Conversação (p. ex., LEVINSON, 1983; GOODWIN; HERITAGE, 1990) explicam como estudantes constroem de modo colaborativo aproximações sofisticadas para conceitos científicos. Roschelle (1996) identifica a participação democrática, o progresso intelectual e a convergência gradual como sendo as práticas de base da inquirição social que possibilitam aos cientistas passar pela mudança conceitual. Ele conclui que, no curso da interação conversacional colaborativa, os estudantes desenvolvem seus próprios conceitos através de práticas de inquirição similares àquelas empregadas pelas comunidades científicas.

O conceito de convergência levanta algumas questões significativas. O entendimento usual do termo sugere um acordo explícito. Isso certamente é apropriado quando se trata de grupos orientados a uma tarefa, os quais devem atingir e implementar decisões. O consenso é também um objetivo pedagogicamente válido quando o material ensinado são fatos ou teorias científicas. Todavia, o consenso pode ser muito mais do que se espera em muitas discussões nas áreas de Humanidades e Ciências Sociais, embora algum grau de entendimento sobre as visões de outros seja geralmente atingível (BURBULES, 1993).

O objetivo ali é possibilitar aos estudantes apreender os termos da controvérsia rigorosamente, uma vez informados do contexto disciplinar e dos conceitos. A busca por essa espécie de convergência é mais heurística do que substantiva. Portanto, é um lugar-comum entre os professores concluir uma discussão antes que todos estejam num acordo, dado que o vaivém da argumentação já mostrou as várias posições com clareza. Isso é um procedimento válido pedagogicamente, em que a meta da educação é mais o esclarecimento individual do que a realização de uma decisão prática ou a indução a uma profissão científica.

A literatura educacional mais recente adotou a premissa de que uma experiência educacional bem-sucedida deve levar em conta tanto o mundo pessoal do aprendiz como o mundo circundante compartilhado. O contexto social afeta enormemente o processo e o resultado do aprendizado. Lipman (1991) nota que a comunidade de inquirição promove o

\begin{tabular}{|c|c|c|c|c|}
\hline Q Rovista Dialectus & Ano 9 & n. 17 & Maio - Agosto 2020 & p.182-211 \\
\hline
\end{tabular}




\section{A PEDAGOGIA NO ESPACO CIBERNÉTICO: A DINÂMICA...}

Cindy Xin / Andrew Feenberg pensamento crítico. O Construtivismo Colaborativo de Garrison e Archer (2000) revela que a educação envolve as atividades complementares da construção individual do significado e da enculturação social.

Se o aprendizado envolve necessariamente as duas atividades complementares da interação em grupo e da reflexão pessoal, como uma conferência por computadores poderia facilitá-lo e sustentá-lo? Para responder essa questão, examinaremos brevemente a literatura recente em diálogo com a inquirição educativa e crítica.

Uma série de autores contemporâneos discutiram as implicações pedagógicas do diálogo. Burbules (1993) identifica quatro tipos de diálogo usados no ensino: conversação, inquirição, debate e instrução. Gadamer (1982) considera o diálogo como o processo primário através do qual as pessoas atingem um entendimento mútuo. A aquisição de conhecimento envolve refletir sobre vários horizontes cognitivos que levam à mudança conceitual através da fusão do horizonte próprio de alguém com aquele de outrem. No processo educacional, supõese que a fusão sirva para alargar o horizonte dos estudantes a fim de este abarque elementos da tradição disciplinar. Bruffee (1999) afirma que o ensino universitário se refere a uma negociação dentro dos limites estabelecidos entre os membros das comunidades acadêmicas e os estudantes que desejam nelas ingressar. A tarefa professoral consiste, assim, em conectar os horizontes dos estudantes às respectivas comunidades acadêmicas por eles pretendidas.

Um dos maiores objetivos do diálogo online é promover a inquirição crítica (também conhecida como pensamento crítico) e o aprendizado profundo (NEWMAN, JOHNSON, COCHRANE; WEBB, 1997). A inquirição crítica é geralmente descrita como um processo de obtenção de entendimento através da inquirição lógica ou raciocínio, da avaliação crítica, da solução de problemas e da tomada racional de decisão. O estudo de Kanuka e Kreber (1999) falhou em mostrar a relação entre métodos de instrução e altos níveis de construção de conhecimento no ambiente online. Porém, os resultados de um estudo posterior de Kanuka (2005) sustentam a posição de que tecnologias de comunicação na internet baseadas em textos podem facilitar ambientes de aprendizado efetivo através do uso de certas estratégias de instrução, tendo assim a capacidade de facilitar níveis mais altos de aprendizado.

Garrison (1991) traça em cinco estágios um modelo de pensamento crítico aplicado à solução de problemas em relação ao aprendizado de adultos. Os cinco estágios incluem a identificação do problema, a definição, a exploração, a aplicabilidade e a integração. Esses estágios descrevem os processos de iniciação do interesse num problema, definição dos

\begin{tabular}{|c|c|c|c|c|}
\hline Q Rovista Dialectus & Ano 9 & n. 17 & Maio - Agosto 2020 & p.182-211 \\
\hline
\end{tabular}




\section{A PEDAGOGIA NO ESPACO CIBERNÉTICO: A DINÂMICA...}

Cindy Xin / Andrew Feenberg

limites do problema, identificação de fins e meios, exploração, desenvolvimento, comparação, estruturação de novas ideias e soluções, acesso crítico a ideias, avaliação de soluções e, finalmente, ação sobre esses entendimentos para validar o conhecimento. O modelo de Garrison serviu de base para alguns importantes estudos posteriores.

Baseado no modelo original de Garrison (1991), um estudo recente de Garrison, Anderson e Archer (2001) define quatro fases da inquirição racional em conferência por computadores: a geração do evento, a exploração, a integração e a resolução. A geração do evento é uma questão ou um problema apresentado para discussão. Depois disso, a discussão entra na fase exploratória em que os participantes alternam entre pensamento reflexivo individual e discurso público em grupo; essa fase é caracterizada pela troca de informações, pelo brainstorming, pelo questionamento e pela clarificação. A terceira fase é a integração, descrita como a construção de sentido baseada nas ideias geradas na fase exploratória. A integração é caracterizada pelos atos de acessar, conectar e sintetizar ideias e de criar soluções. A inquirição conclui-se com a fase da resolução, na qual os participantes implementam soluções propostas ou hipóteses de teste por meio de aplicações práticas ou experimentos de pensamento. Os participantes geralmente continuam a construção de consenso nesta fase até estarem prontos para progredir a um tema novo, o qual inicia uma nova rodada de inquirição crítica em quatro fases.

Outro notável estudo feito por Gunawardena, Lowe e Anderson (1997) identifica cinco fases típicas de negociação e construção conjunta de conhecimento num debate online entre muitos profissionais de educação a distância. As cinco fases são: $\left(1^{\text {a }}\right)$ o compartilhamento / a comparação de informações, $\left(2^{a}\right)$ a descoberta da dissonância e insistência, $\left(3^{a}\right)$ a negociação de sentido e a construção conjunta de conhecimento, $\left(4^{\mathrm{a}}\right)$ o teste e a modificação da síntese proposta, $\left(5^{\mathrm{a}}\right)$ o acordo / a aplicação de significados novamente construídos. Na fase 1, os participantes identificam os problemas, declaram os acordos e desacordos, providenciam os exemplos de apoio e classificam as afirmações por meio de questões e respostas. Na fase 2, as áreas de desacordo são identificadas e clarificadas. Na fase 3, os participantes negociam o acordo e o compromisso e propõem a integração de metáforas. Na fase 5, os participantes testam a síntese proposta contra os esquemas cognitivos existentes, os dados e a prova. $\mathrm{Na}$ fase 5, os participantes sumarizam o acordo, aplicam o conhecimento e ilustram a mudança por meio de afirmações metacognitivas.

\begin{tabular}{|c|c|c|c|c|}
\hline Rovista Dialectus & Ano 9 & n. 17 & Maio - Agosto 2020 & p.182-211 \\
\hline
\end{tabular}




\section{A PEDAGOGIA NO ESPACO CIBERNÉTICO: A DINÂMICA...}

Cindy Xin / Andrew Feenberg

Os três modelos acima, de Garrison (1991), de Garrison et al. (2001) e de Gunawardena et al. (1997), representam a construção de conhecimento online como um processo de desenvolvimento, de incremento e de iteração. Embora os modelos difiram um pouco, cada um retrata o começo, meio e fim de cada fase, marcando um avanço em direção à complexidade intelectual crescente, à medida que o grupo vai da divergência para a convergência e os membros individuais atingem um entendimento mais profundo. Portanto, apesar das diferenças entre si, eles descrevem os mesmos processos gerais do desenvolvimento de uma breve conversa inicial, com pouca conexão, à discussão de um tema partilhado, até a resolução de desacordos numa conclusão convergente.

Em seguida, clarificaremos a condição cognitiva subjacente à interação grupal, através da qual os indivíduos estabelecem uma base comum de significados e ferramentas cognitivas que possibilitam o discurso conjunto. Realmente, a menos que os indivíduos apreendam uns dos outros os pensamentos e os sentimentos e compartilhem uma linguagem comum, eles não podem funcionar juntos de modo produtivo. Esses entendimentos são geralmente operativos na conversação sem necessariamente aparecer como temas de discussão. Por contraste, a convergência ocorre quando o grupo chega a um único ponto de vista sobre o assunto por meio de um argumento explicitamente articulado. A convergência, enquanto assentimento mútuo e consenso, pressupõe o nível mais fundamental de linguagem compartilhada e as suposições empregadas na discussão, mas não é idêntica ao background propiciador. A obtenção desse tipo de comunidade de pensamento e sentimento não se conforma aos modelos de engajamento intelectual, mas tem seus próprios procedimentos muito menos lógicos, os quais examinamos na próxima seção.

\section{A comunicação e a base comum}

A conversa online consiste de muitos processos de fundo quase invisíveis que possibilitam a comunicação fluir. Esses processos têm sido amplamente negligenciados na teoria educacional, a qual se concentra na troca intelectual pela qual os interlocutores propõem ideias e asserções factuais e argumentam mais ou menos logicamente sobre sua validade. Mas esse processo de primeiro plano só é possível porque uma base comum já estabelecida de suposições possibilita a comunicação em primeiro plano. Eis a negligenciada base da conversa online.

\begin{tabular}{|c|c|c|c|c|}
\hline Qevista Dialectus & Ano 9 & n. 17 & Maio - Agosto 2020 & p.182-211 \\
\hline
\end{tabular}




\section{A PEDAGOGIA NO ESPACO CIBERNÉTICO: A DINÂMICA...}

Stalnaker (1978) a descreve deste modo:

Grosso modo, as pressuposições de um falante são as proposições cuja verdade ele assume como parte do background da conversação [...] As pressuposições são aquilo que é considerado pelo falante como a base comum dos participantes na conversação, o que é tratado como o conhecimento comum ou conhecimento mútuo. (STALNAKER, 1978, p. 320).

Como a conversação aumenta essa base comum? Segundo Clark e Schaefer (1989), as conversações são atividades altamente coordenadas que são feitas de performances coletivas pelos participantes que trabalham juntos. Tais performances incluem os esforços do falante em curso para garantir que foi atendido, ouvido e compreendido pelos outros participantes; elas devem, por sua vez, deixar o falante saber quando falhou ou obteve sucesso. Entendida nesses termos, o processo de comunicação não é redutível a uma sequência lógica de proposições. É um processo social em que interações contingentes, improvisações e negociações sobre o significado produzem continuamente a base para maior interação. A lógica de superfície do diálogo educacional é sustentada por um padrão diferente da troca comunicativa que faz sentido para ser clara, mas só contextualmente e como um processo temporariamente revelador.

No modelo de Clark e Schaefer (1989), a "contribuição para o discurso" (CPD) é definida como uma unidade de conversação que consiste na especificação do conteúdo e na fundamentação dele. $\mathrm{Na}$ especificação do conteúdo, o contribuinte apresenta uma contribuição e o parceiro estabelece uma crença mútua de que o entendimento foi alcançado. Portanto, as contribuições para o discurso consistem em duas fases essenciais, a apresentação e a aceitação. É somente através da realização bem-sucedida de ambas as fases que os participantes constroem coletivamente a sua base comum.

Para sustentar seu modelo CPD, Clark e Schaefer (1989) identificam cinco tipos principais de evidência de entendimento ou aceitação. A é o apresentador e B é o receptor:

1. Atenção contínua: B mostra que ele continua a prestar atenção e, portanto, permanece satisfeito com a apresentação de A.

2. Iniciação da próxima contribuição relevante: B começa uma nova contribuição que seria relevante num nível tão alto quanto o atual.

3. Reconhecimento: B acena ou diz "Entendi", "Sim” ou palavras similares.

4. Demonstração: B demonstra tudo ou parte do que ele entendeu do que A expressou.

\begin{tabular}{|l|l|l|l|l|}
\hline Q & Movista & Maio - Agosto 2020 & p.182-211 \\
\hline
\end{tabular}




\section{A PEDAGOGIA NO ESPACO CIBERNÉTICO: A DINÂMICA...}

Cindy Xin / Andrew Feenberg

5. Exibição: B exibe tudo ou parte da apresentação de A, palavra por palavra. (CLARK e SCHAEFER, 1989, p. 267).

Esses tipos de evidência são classificados grosso modo desde o mais fraco até o mais forte. A atenção contínua ou a iniciação de próxima contribuição relevante oferece a evidência menor de entendimento. O reconhecimento, a demonstração e a exibição oferecem, a cada uma, maior evidência de entendimento.

O reparo é um subprocesso discursivo essencial que consiste em corrigir malentendidos. Isso é importante para a significação e é um ingrediente necessário no modelo de Clark e Schaefer (1989). Para alcançar a fundamentação de modo consistente, os participantes devem não somente reparar algum problema que encontraram, mas também tomar medidas positivas para, em primeiro lugar, estabelecer um entendimento e evitar qualquer problema. Isso é mais difícil online do que face a face.

Com modificações significativas, o modelo CPD sugere uma estrutura para analisar discursos em conferências online.

Primeiro, o modelo é baseado no caso mais simples de uma conversa entre dois participantes. O processo do discurso de muitos para muitos, em tempo real ou assíncrono, face a face ou online, é muito mais complexo porque o entendimento é alcançado gradualmente pelo crescente número de participantes. A discussão grupal em educação confia, portanto, num moderador para garantir uma adequada tomada de palavra e manter o processo de avançar na correta direção. Essa função é realizada através do exercício do que chamados de "funções moderadoras", o que será discutido detalhadamente a seguir.

Em segundo lugar, o modelo CPD descreve a conversação face a face. Quando é online, sem pistas visuais e verbais, e quando os participantes se comunicam de modo assíncrono, os problemas que requerem reparo não podem ser identificados prontamente. $\mathrm{O}$ reparo também requer, portanto, o exercício de liderança online para garantir o adequado fluxo da discussão.

Em terceiro lugar, quase todos os exemplos dados para ilustrar o modelo CPD são retirados de conversas quotidianas breves, triviais. O discurso colaborativo engajado diz respeito a significados profundamente elaborados relacionadas a um assunto bem definido e explorado ao longo de um período considerável. Embora os processos fundamentais do modelo CPD sirvam para esse tipo de discurso, este está necessariamente numa estrutura um pouco diferente.

\begin{tabular}{|l|l|l|l|l|}
\hline Q & Disista & Maio - Agosto 2020 & p.182-211 \\
\hline
\end{tabular}




\section{A PEDAGOGIA NO ESPACO CIBERNÉTICO: A DINÂMICA...}

Cindy Xin / Andrew Feenberg

Finalmente, embora o conceito básico de apresentação e aceitação se sustente, nem todas as evidências de entendimento identificadas no modelo CTD se aplicam à conferência por computadores; por isso, sua relativa força varia. Examinamos abaixo cinco tipos de evidência nesse contexto.

A atenção contínua numa conversação face a face indica que ao apresentador A que o receptor B entendeu o que A disse; o silêncio significa que A pode estar confiante de ter sido bem-sucedido nos propósitos atuais e que deve continuar a apresentação. Porém, o silêncio online é geralmente um enigma para o apresentador, uma fonte de ansiedade na comunicação (FEENBERG, 1989). Não está claro se significa acordo, educada desaprovação, indiferença ou então a completa ausência do receptor na conferência. No ambiente online, somente a evidência explícita de entendimento conta.

Por várias razões, a exibição é menos efetiva online do que face a face. Exibir ou repetir as palavras exatas do contribuinte não revela por si só compreensão, já que qualquer texto pode ser retomado de forma mecânica.

A iniciação de uma próxima contribuição relevante pode fornecer uma evidência válida online, embora de modo menos efetivo do que a conversação face a face. O problema é o tempo. A análise da conversação assume implicitamente a sincronicidade da fala face a face. Isso é óbvio no contexto em que a próxima contribuição relevante deve ser proferida durante um pequeno intervalo para valer como aceitação. Se ela for além desse pequeno período, ela aparecerá como outra apresentação original. Como esses efeitos de tempo não podem ser obtidos sem ambiguidade no discurso online assíncrono, essa forma de aceitação não é sempre bem-sucedida.

A mais forte evidência de entendimento online, a única que realmente não é ambígua, é a reformulação da apresentação do contribuinte nas próprias palavras do interlocutor ou a aplicação correta dos conceitos aprendidos em novas situações. Isso coloca um fardo considerável nos interlocutores: eles devem interagir explicitamente em torno do conteúdo das mensagens de cada um, para que assim estejam seguros do entendimento mútuo. Mas esse fardo é útil em educação: quanto mais profundamente os participantes interagirem, mais bemsucedidos eles serão em avançar a agenda do curso e em alcançar a mudança conceitual individual.

A análise da tradicional conversação rende muitos insights dentro do processo de conversa face a face. Recentemente esse tipo de análise se tornou uma relevante abordagem

\begin{tabular}{|c|c|c|c|c|}
\hline Govista Dialectus & Ano 9 & n. 17 & Maio - Agosto 2020 & p.182-211 \\
\hline
\end{tabular}




\section{A PEDAGOGIA NO ESPACO CIBERNÉTICO: A DINÂMICA...}

Cindy Xin / Andrew Feenberg

de pesquisa qualitativa para o exame de fenômenos educacionais relacionados ao discurso mediado por computadores (MAZUR, 2003). O artigo abrangente de Mazur, no Manual de pesquisa para comunicações educacionais e tecnologia, explora as questões teóricas e metodológicas para a pesquisa das estruturas, dos processos e do significado da conversa online. Com as modificações sugeridas neste artigo, os insights que identificamos podem ser aplicados para se entender a produção da base comum dos grupos online.

Considerados dinamicamente, os três modelos de discurso colaborativo e de inquirição crítica apresentados acima sugerem um desenvolvimento progressivo em que o fim de cada ciclo de aprendizado se torna o começo do próximo círculo. O modelo CPD oferece insights sobre esse processo: a comunicação se aprofunda através de uma série de tentativas para explicar, verificar, reparar e confirmar o assunto da discussão; cada ciclo começa com uma base comum alargada resultante de um entendimento comum e de uma convergência grupal até então alcançada. Artefatos de um novo conhecimento são compartilhados no grupo até o fim de cada ciclo de diálogo; esses objetos compartilhados devem ser apropriados pelos indivíduos para o engajamento nas atividades colaborativas do próximo ciclo. O engajamento intelectual se baseia na base comum durante o processo de compartilhamento, questionamento, negociação, teste e sintetização de conhecimento.

\section{A relação entre processos intelectuais e comunicativos}

Voltamos agora à relação entre os processos de fundo e os processos de primeiro plano do engajamento intelectual.

Para descrever o engajamento intelectual e o processo de comunicação de muitos para muitos, apresentamos um modelo trifásico de discurso que leva em conta a complexidade da construção da base comum e do entendimento compartilhado num grupo (cf. abaixo a Figura 2). Chamamos essas três fases de "iniciação de assunto", "diálogo múltiplo" e "diálogo em comum". Cada fase possui aspectos de plano de fundo e de primeiro plano. O engajamento intelectual constitui o primeiro plano que possibilita a mudança conceitual individual e a convergência grupal. Os processos de comunicação constituem o plano de fundo que constrói a base comum à medida que os entendimentos compartilhados são apresentados na discussão.

\begin{tabular}{|l|l|l|l|l|}
\hline Q & Movista & Maio - Agosto 2020 & p.182-211 \\
\hline
\end{tabular}




\section{A PEDAGOGIA NO ESPACO CIBERNÉTICO: A DINÂMICA...}

Cindy Xin / Andrew Feenberg

$\mathrm{Na}$ Figura 2, os quadrados representam os participantes, os círculos representam as contribuições e as ovais a base comum. Os círculos sobrepostos no último estágio representam a convergência parcial alcançada por meio da discussão.

Embora apresentemos o engajamento intelectual e a comunicação como processos de desenvolvimento que avançam por meio de fases com começo, meio e fim, não queremos dizer por implicação que a discussão online segue tipicamente um nítido processo linear. Descrevemos uma tendência de desenvolvimento geral que dependem da vontade dos estudantes e professores para proceder mais ou menos metodicamente por meio de algum tipo de conclusão compartilhada. Porém, como na conversação quotidiana em grupo, a discussão online é um processo iterativo com frequentes digressões e complicados processos de reparo. Abaixo descreveremos em pormenor o modelo.

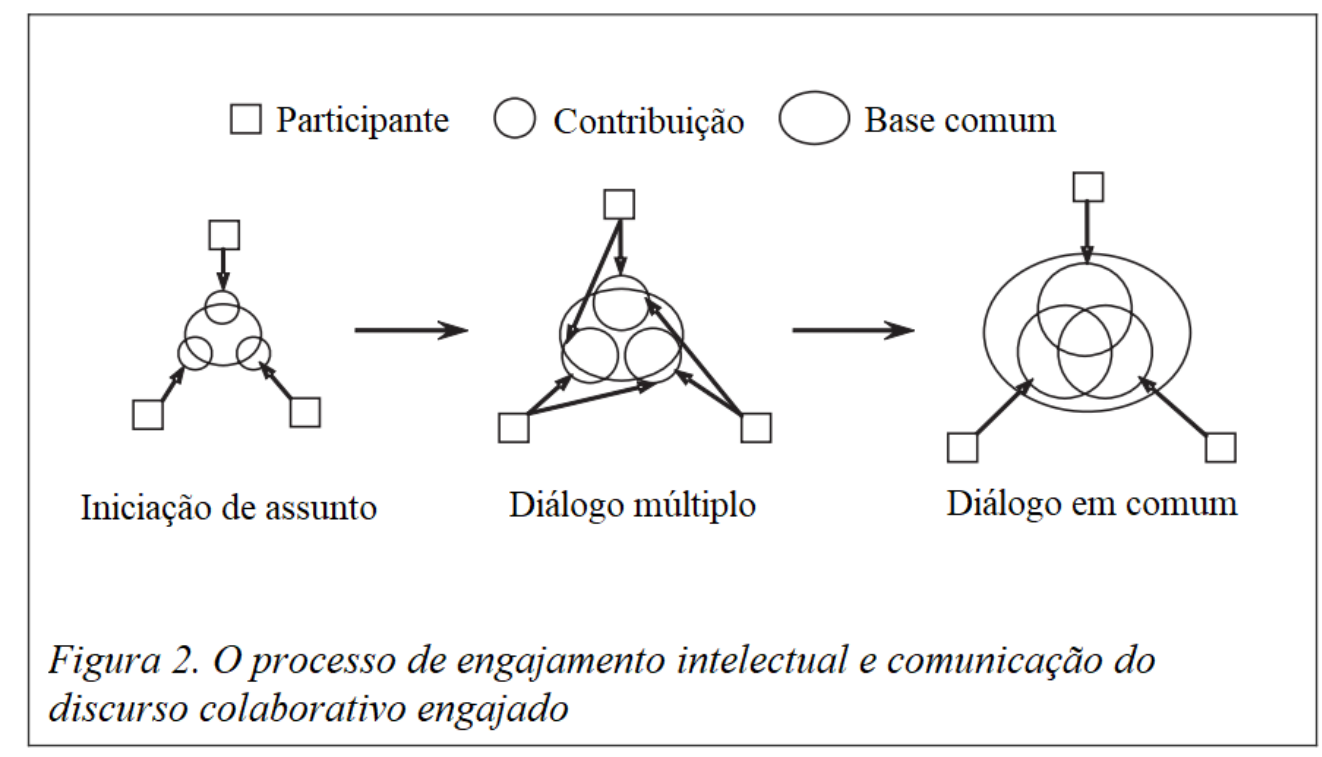

Fase 1. A iniciação de assunto

O primeiro plano. Durante a fase inicial, um assunto (por exemplo, um problema ou uma questão) é proposto para discussão, e os participantes individuais respondem por apresentar seus próprios pensamentos e sentimentos, observações pessoais e exemplos. $\mathrm{O}$ engajamento intelectual nessa primeira fase não visa geralmente a obtenção de acordo, mas, ao contrário, a definição de termos e limites do problema, a clarificação de afirmações e de contexto, e a proposição de abordagens.

\begin{tabular}{|l|l|l|l|l|}
\hline Govista 2 Dialectus & Ano 9 & n. 17 & Maio - Agosto 2020 & p.182-211 \\
\hline
\end{tabular}




\section{A PEDAGOGIA NO ESPACO CIBERNÉTICO: A DINÂMICA...}

Cindy Xin / Andrew Feenberg

O plano de fundo. No curso dessas atividades, os participantes começam a identificar a base comum dentre as ideias, suposições e experiências que cada um trouxe para a discussão. A base comum nessa fase não pode estender para muito além os valores e as experiências compartilhados que os participantes trazem para a discussão de suas vidas offline. A possibilidade de haver mal-entendidos é considerável.

As contribuições para a discussão nessa fase têm um propósito implícito que não pode ser totalmente perceptível: testar os limites do entendimento compartilhado para estabelecer a base comum inicial do grupo. Ao final dessa fase, os participantes devem ter um sentimento de que podem desenvolver alguns conceitos básicos sem ser mal compreendidos. O acesso igualitário e a participação distribuída são essenciais na fase inicial de modo que o máximo possível de participantes possa se engajar nesse processo de teste de entendimentos básicos.

\section{Fase 2. O diálogo múltiplo}

$O$ primeiro plano. $\mathrm{O}$ processo de engajamento intelectual nessa fase leva ao entendimento aprofundado sobre o melhor modo de resolver o problema posto na fase de iniciação de assunto. A fase do diálogo múltiplo inicia a mudança conceitual em nível individual. A convergência da opinião entre subgrupos informais vai se formando gradualmente e, ao menos para algumas questões, o consenso é alcançado no interior do grupo como um todo. A discussão avança na medida em que o professor introduz conceitos disciplinares e métodos e testa o entendimento dessas novas ideias. Durante a segunda fase, os participantes concordam ou discordam, clarificam e elaboram, refletem e organizam, bem como tentam justificar ideias, posições e soluções propostas na fase precedente.

O plano de fundo. Correspondendo a essas atividades, a base comum é alargada em padrões desiguais no grupo. Nessa fase, os horizontes dos indivíduos são levados em consideração e desafiados, às vezes fortalecidos, às vezes enfraquecidos, mas, ao final, estendidos. Os elementos da tradição disciplinar são absorvidos dentro desse processo e oferecem novas ferramentas cognitivas. Esse processo é constituído de muitas rodadas de apresentação e aceitação, tal como foi definido por Clark e Schaefer (1989). Mas, apesar da aparente linearidade de seu modelo, conforme a simplificada apresentação que acima fizemos, o diálogo múltiplo não segue necessariamente um caminho suave. Na conferência por computadores, frequentemente se observam múltiplas apresentações e aceitações simultâneas,

\begin{tabular}{|c|c|c|c|c|}
\hline Qovista Oialectus & Ano 9 & n. 17 & Maio - Agosto 2020 & p.182-211 \\
\hline
\end{tabular}




\section{A PEDAGOGIA NO ESPACO CIBERNÉTICO: A DINÂMICA...}

Cindy Xin / Andrew Feenberg ou complexas sequências de apresentação, de rejeições, de reparos e, posteriormente, de aceitações. No final dessa fase, os entendimentos, que foram muito além da base comum inicial, são estabelecidos no grupo como um todo.

\section{Fase 3. O diálogo em comum}

O primeiro plano. Uma vez que o grupo é equipado com um número considerável de artefatos de conhecimento compartilhado e clarificou os termos do seu discurso, uma nova fase de engajamento intelectual pode começar. Essa fase leva à convergência relativa sobre uma decisão e/ou solução por meio da síntese e da integração de argumentos estabelecidos com fundamento na base comum. Como foi visto, em alguns campos a busca de acordo é mais importante do que sua obtenção. É esse processo que finalmente leva os indivíduos em aprendizagem à aquisição de um novo conhecimento.

O plano de fundo. Eis, portanto, a fase final que leva à fusão geral de horizontes que abarca tanto os estudantes individuais como também a tradição disciplinar representada pelo professor (GADAMER, 1982). Nessa fase, a base comum é alargada para abranger todo o grupo no curso de desenvolvimento dos recursos cognitivos compartilhados já existentes, a fim de resolver as questões disponíveis. Mesmo onde nem todos chegam às mesmas conclusões, o aprendizado ocorre no processo de discussão das diferenças. O entendimento compartilhado, mais do que o acordo unânime, é então outra possibilidade advinda da fusão de horizontes.

Como a descrição nos mostra, os dois processos básicos - o engajamento intelectual e a comunicação - são entrelaçados e inseparáveis. Eles são aspectos de um único e mesmo processo da discussão online. No primeiro plano, o grupo luta por mudança conceitual e convergência. No plano de fundo, os participantes sustentam o discurso e constroem sua base comum. A base comum é o recurso que fornece artefatos de conhecimento compartilhado, os quais são usados pelos participantes ao articularem suas posições e ao desenvolverem soluções. Por sua vez, os resultados da construção de conhecimento são depositados no plano de fundo e contribuem para a base comum mobilizada no próximo estágio da discussão. Essa interação recíproca forma um sistema de suporte mútuo na medida em que o efeito da comunicação ajuda o processo de construção de conhecimento e vice-versa.

\begin{tabular}{|l|l|l|l|l|}
\hline Q & Movista & Maio - Agosto 2020 & p.182-211 \\
\hline
\end{tabular}




\section{Os aspectos sociais}

Aqui discutimos a liderança e a motivação online, os aspectos sociais do discurso colaborativo engajado que são os mais desafiadores para os professores. Identificamos as motivações para o aprender que são geradas pela dinâmica da discussão e que mostram como a moderação efetiva pode ajudar a sustentar a conversação e avançá-la em direção a objetivos pedagógicos.

\section{O diálogo e a motivação}

No Mênon, Sócrates conduz um jovem escravo pelas etapas de uma prova geométrica. $\mathrm{O}$ diálogo exemplifica uma abordagem pedagógica que funciona pelo questionamento do aprendiz apenas até o nível de dificuldade que é apropriado ao entendimento atual dele. $\mathrm{O}$ estudante é auxiliado a fazer conexões mentais ativas, frequentemente chamadas por teóricos educacionais de construção de conhecimento, sem saltos conceituais forçados ou prematuros.

Para questionar no nível certo de dificuldade, o professor deve medir a distância entre o "nível de desenvolvimento atual, determinado pela habilidade independente de resolver problemas", e o "nível de desenvolvimento potencial, determinado pela habilidade de resolver problemas sob orientação ou em colaboração com pares mais capazes" (VYGOTSKY, 1978, p. 86). Vygotsky define essa distância como "zona de desenvolvimento proximal”. O aprendizado envolve o professor em diálogo com o estudante, adicionando níveis de suporte apropriados ao estado de prontidão do estudante e que podem ser gradualmente retirados conforme o entendimento do assunto amadurece. Isso é descrito tal como uma colocação de andaimes (WOOD, 1999).

A atividade na zona de desenvolvimento proximal é árdua, mas gratificante no âmbito emocional. De modo similar, o diálogo não é meramente um processo cognitivo, mas envolve a pessoa inteira. Todo aquele que já participou de uma animada discussão recolhe a excitação da interação e da descoberta que estimula um grau incomum de atenção e envolvimento. Isso não é menos verdadeiro no ambiente online, onde a excitação gerada pela discussão é até mais essencial para a manutenção da participação do que no diálogo face a face. Chamamos de "intrínsecas" as motivações que surgem da própria natureza do diálogo, por contraste àquelas motivações extrínsecas que são requisitos para a participação. As motivações extrínsecas

\begin{tabular}{|l|l|l|l|l|}
\hline Q ovista Dialectus & Ano 9 & n. 17 & Maio - Agosto 2020 & p.182-211 \\
\hline
\end{tabular}




\section{A PEDAGOGIA NO ESPACO CIBERNÉTICO: A DINÂMICA...}

Cindy Xin / Andrew Feenberg

incluem o suspense provocado pela espera por respostas, a surpresa com intervenções inesperadas e o sentimento de realização que advém do reconhecimento de outros e da obtenção bem-sucedida de novas ideias.

Os esportes e jogos oferecem metáforas para essa peculiar sociabilidade amparada por tais motivações. Os jogadores visam uma meta externa à ação de jogar, tal como vencer, mas a cada rodada de jogo seus movimentos são provocados e provocam respostas por causa de razões intrínsecas, tais como a excitação de tomar a bola de um adversário. O jogo consiste num ir e vir de movimentos e contramovimentos tendo a vitória como horizonte, sob o qual as interações acontecem. Na realidade, o diálogo parece mais um relaxante bate-rebate do que um jogo sério. O que se quer é que o outro rebata de volta, e o propósito não é ganhar, mas melhorar suas próprias jogadas. De modo similar, cada mensagem no diálogo educacional cumpre uma dupla meta: comunicar um conteúdo e evocar uma resposta adicional. O verdadeiro prazer de entrar em ação numa discussão online é fazer movimentos que mantenham os demais em ação (FEENBERG, 1989; FEENBERG; XIN, 2002).

Goffman (1961) emprega os termos absorção e deleitação para descrever a força que leva pessoas a um jogo. O discurso colaborativo online tem uma fascinação comparável àquele. A lógica do desdobramento de uma discussão nos engaja até o ponto em que somos completamente absorvidos pela ação, e ela rapidamente antecipa o próximo movimento. A deleitação se deve ao processo do diálogo por si só. O que possibilita a comunidade online em educação não é tanto as ligações sentimentais formadas por intimidades pessoais, mas o prazer de profunda satisfação da deleitação num jogo dialogal. Isso, por sua vez, cria o elo emocional da comunidade (XIN, 2002).

A liderança efetiva de um moderador é essencial para manter os participantes absorvidos e o jogo em andamento. O moderador define e modela normas de comunicação e de comportamento que funcionam como algo equivalente às regras de um jogo. O moderador deve continuamente se certificar de que essas normas estão sendo observadas a fim de assegurar o fluxo da discussão. Abaixo, temos ainda mais algumas coisas a dizer sobre a moderação.

A dinâmica de grupo e a liderança

\begin{tabular}{|l|l|l|l|l|}
\hline Q Rovista Qialectus & Ano 9 & n. 17 & Maio - Agosto 2020 & p.182-211 \\
\hline
\end{tabular}




\section{A PEDAGOGIA NO ESPACO CIBERNÉTICO: A DINÂMICA...}

Cindy Xin / Andrew Feenberg

Durante anos houve uma demanda para que o aprendizado centrado no professor mudasse para o aprendizado centrado no estudante. Isso é caracterizado muito bem pelo bordão popular que convida o professor a ser "um orientador que está ao lado" em vez de "um sábio no palco". Muitos educadores celebram a conferência por computadores como sendo um ambiente ideal para implementar o aprendizado centrado no estudante.

Mas será que um facilitador que permanece ao lado pode atingir as metas da educação? Dewey (1938, pp. 62-64), que geralmente é identificado com a abordagem centrada no estudante, argumenta de modo eloquente que "a mera remoção do controle externo" não pode garantir "a produção do autocontrole". O aprendizado ocorre, acredita Dewey, quando os professores exercem indiretamente o controle através de um "trabalho que se faz enquanto empreendimento social, em que todos os indivíduos têm oportunidade de contribuir e com o qual todos se sentem responsáveis" (Ibidem, p. 56). De modo similar, neovygotskianos acreditam que os indivíduos que estão aprendendo constroem o conhecimento conceitual mais por meio de uma instrução orientada do que por uma exploração independente solitária (KOZULIN, 2003; MERRILL, 1992). Tal consideração se aplica especialmente ao ambiente online, onde o processo de comunicação é frágil e pouco familiar tanto para professores como para estudantes. Por causa disso, estudiosos e professores têm reconhecido que a liderança é essencial para se chegar ao discurso efetivo (ANDERSON, ROURKE, GARRISON; ARCHER, 2001; BERGE, 1995; FEENBERG, 2000; HILTZ; TUROFF, 1978; ROSSMAN, 1999).

Isso posto, precisamos evitar um possível mal-entendido. Não significamos com "liderança" uma ênfase unilateral na autoridade do professor. As atividades de liderança em qualquer grupo, incluindo aulas online, podem ser mais ou menos compartilhadas entre os membros. É claro que estudantes esperam que professores desempenhem o papel da liderança principal, e isso é geralmente necessário para um ensino bem-sucedido. Porém, aulas de discussão funcionam da melhor forma quando muitos participantes lideram pequenas partes sob a direção do professor.

Algumas das funções mais importantes da liderança incluem fazer os participantes se sentirem bem-vindos, introduzindo uns aos outros, encorajando-os a trabalhar em grupo harmoniosamente e resolvendo conflitos pessoais ou mal-entendidos. Essas funções são comuns a todos os grupos que se orientam por tarefas, sejam online ou offline. Porém, a 


\section{A PEDAGOGIA NO ESPACO CIBERNÉTICO: A DINÂMICA...}

Cindy Xin / Andrew Feenberg educação envolve atividades específicas que combinam funções sociais e cognitivas da liderança. Nós enfocaremos essas atividades agora.

O conhecimento disciplinar extensivo diferencia professores e estudantes. Quanto a isso, há pouca diferença entre ensinar numa sala de aula e ensinar online. Porém, introduzir o conhecimento disciplinar em conferências por computadores deve contribuir para a discussão sem interrompê-la. A melhor maneira de fazer isso não é óbvia, mas requer uma escolha pedagógica.

Professores frequentemente introduzem ou demasiado ou escasso conteúdo para sustentar a discussão. Conteúdo em demasia torna a discussão uma preleção. Na sala de aula, o preletor deve atuar e entreter para manter a atenção dos estudantes. Embora seja uma apresentação de uma única pessoa, muito da interação entre o preletor e a audiência acontece através de uma implícita comunicação não verbal. No ambiente online, apresentações excessivas do professor dão pouca chance para que o conteúdo seja absorvido através da negociação e frequentemente impedem que os estudantes contribuam com algo.

$\mathrm{Na}$ outra extremidade do espectro, se o professor introduz muito pouco conteúdo, ele acaba se comportando como um estudante ou se retirando da discussão. Em ambos os casos, os estudantes ou param de conversar completamente ou realizam um bate-papo em que simplesmente conversam segundo o capricho do momento e divagam de um tópico para outro. Por mais interessantes e informativos que possam ser esses bate-papos, os estudantes perderam a oportunidade de serem introduzidos na tradição disciplinar da comunidade de saber à qual pertence o professor.

Para ser efetivo na discussão online, o professor deve ser sensível à dinâmica da conversação, injetar conhecimento especializado quando for apropriado e conectar as contribuições dos estudantes na área. Essas tarefas devem ser entrelaçadas com as funções sociais e comunicativas da moderação.

Vários estudos fornecem insights sobre a moderação. Feenberg (1989) enfatiza as diferenças entre a discussão online e a discussão face a face sob uma perspectiva comunicativo-teórica e destaca as performances comunicativas específicas que pertencem à função da moderação online. Ele argumenta que manejar uma conferência bem-sucedida requer uma liderança forte, mas não dominadora, por meio de complexas intervenções comunicativas. Seus primeiros artigos definem um conjunto de funções moderadoras, classificando-as sob três categorias, como se vê a seguir.

\begin{tabular}{|l|l|l|l|l|}
\hline Q & Disista & Maio - Agosto 2020 & p.182-211 \\
\hline
\end{tabular}




\section{A PEDAGOGIA NO ESPACO CIBERNÉTICO: A DINÂMICA...}

Funções contextualizadoras. Essas funções fornecem uma estrutura compartilhada de regras, papéis e expectativas ao grupo.

Funções monitoradoras. Essas funções ajudam os participantes a saber se seguiram com sucesso as normas do grupo e cumpriram as expectativas assentadas por eles.

Metafunções. Essas funções têm a ver com a gestão do processo e do conteúdo e incluem atividades como reparar as associações comunicativas, sintetizar os resultados do engajamento intelectual e designar papéis específicos aos participantes.

Berge (1995) propôs uma classificação amplamente utilizada de atividades de facilitação, em quatro categorias: pedagógica, social, gerencial e técnica. Uma contribuição recente para a literatura por Anderson et al. (2001) apresenta um modelo de aferição da “presença de ensino" em cursos online. A presença de ensino é definida como a extensão em que os participantes, especialmente o professor, são capazes de projetar experiências educacionais, facilitar o discurso e propiciar uma instrução direta. Muitas das categorias funcionais nesses dois últimos estudos se assemelham às funções moderadoras de Feenberg (1989). Porém, esses estudos oferecem insights adicionais. Com base numa síntese dos três modelos, acréscimos foram feitos ao esquema original de Feenberg.

Uma versão revisada dessas funções é apresentada a seguir na Tabela 1 (XIN, 2002; FEENBERG; XIN, 2003).

A dupla face da moderação - social e cognitiva - é a chave para a pedagogia online.

Funções contextualizadoras

1. Abrir discussões. O moderador deve providenciar um comentário de abertura que declara o tema da discussão e estabelece um modelo de comunicação. O moderador pode periodicamente contribuir com sugestões de assuntos ou solicitações que abram discussões maiores dentro da estrutura do tema geral do fórum. 2. Colocar normas. O moderador sugere regras de procedimento para a discussão. Algumas normas são modeladas pela forma e pelo estilo dos comentários de abertura do moderador. Outras são explicitamente formuladas em comentários que estabelecem o estágio da discussão.

3. Colocar a agenda. O moderador gerencia o fórum ao longo do tempo e seleciona um fluxo de temas e tópicos de discussão. O moderador geralmente compartilha parte ou o todo da agenda com os participantes desde o início.

4. Referenciar. A conferência pode ser contextualizada pela referência a materiais disponíveis na internet, por exemplo, hyperlinks ou materiais tais como livros didáticos.

Funções monitoradoras

5. Reconhecer. O moderador se refere explicitamente aos comentários dos participantes para lhes garantir que suas contribuições são valiosas e bem-vindas, ou para corrigir mal-entendidos sobre o contexto da discussão.

6. Solicitar. O moderador endereça aos indivíduos ou ao grupo requisições de comentário. A solicitação inclui fazer questões e pode ser formalizada como deveres ou tarefas. Ela pode ocorrer através de mensagens privadas ou requisições públicas no fórum.

7. Avaliar. As conclusões dos participantes podem ser avaliadas por testes, sessões de revisão ou outros procedimentos formais.

Metafunções

\begin{tabular}{|c|c|c|c|c|}
\hline Q Rovista Dialectus & Ano 9 & n. 17 & Maio - Agosto 2020 & p.182-211 \\
\hline
\end{tabular}


8. Fazer metacomentários. Metacomentários incluem observações referentes a coisas como contexto, normas ou agenda do fórum, ou servem para resolver problemas como falta de clareza, irrelevância e sobrecarga de informação. Metacomentários desempenham um papel importante na manutenção das condições de uma comunicação bem-sucedida.

9. "Tecer". O moderador sintetiza o estado da discussão e encontra nos comentários dos participantes as ameaças à unidade. A tecitura reconhece os autores dos comentários que ela costura, e com frequência lhes solicita implicitamente que continuem ao longo das frentes que fazem avançar a agenda da conferência.

10. Delegar. Certas funções moderadoras, tais como a tecitura, podem ser designadas a participantes individuais para que atuem por um maior ou menor período.

Tabela 1. Resumo das funções moderadoras

\section{As funções moderadoras na dinâmica do discurso colaborativo engajado}

A liderança online dos endereçamentos moderadores efetivos é o problema central da conferência por computadores. Primeiro, como explicado acima, ela realiza a mediação entre o entendimento do assunto pelos estudantes e a tradição disciplinar de modo a possibilitar que se tornem membros de uma comunidade de saber, para cuja entrada estudam.

Em segundo lugar, a moderação medeia cada um dos dois processos subjacentes, a comunicação e o engajamento intelectual, e possibilita o avanço de um estágio a outro. No lado da comunicação, ela sustenta as relações sociais da comunicação e o entendimento mútuo no grupo. Como as mensagens que desempenham funções moderadoras frequentemente encapsulam contribuições cognitivas, o uso efetivo dessas funções cumpre um papel comunicativo e também intelectivo.

Em terceiro lugar, no lado cognitivo, a comunicação e o engajamento intelectual são entrelaçados e inseparáveis. Porém, conectar os dois processos não é sempre fácil. $\mathrm{O}$ engajamento intelectual depende da base comum identificada nas primeiras discussões. Mas como vimos, a aceitação, que é essencial para a produção da base comum, é mais complexa num grupo. Para promover a aceitação, o moderador tematiza explicitamente a base comum estabelecida pelo processo em andamento de engajamento intelectual, de modo que o grupo possa, com confiança, ter como certo o seu próprio horizonte compartilhado. Isso habilita os estudantes a relacionar seus horizontes individuais aos dos outros e orienta as ações coletivas do grupo à próxima fase do engajamento intelectual. A moderação então assegura a construção de uma base comum no auxílio à solução de problemas e à convergência, bem como a construção de conhecimento na promoção do alargamento da base comum estabelecida.

\begin{tabular}{|l|l|l|l|l|}
\hline Qenista Dialectus & Ano 9 & n. 17 & Maio - Agosto 2020 & p.182-211 \\
\hline
\end{tabular}




\section{A PEDAGOGIA NO ESPACO CIBERNÉTICO: A DINÂMICA...}

Cindy Xin / Andrew Feenberg

As funções moderadoras desempenham funções diferentes em várias fases no desdobramento da discussão online. $\mathrm{Na}$ fase de iniciação de assunto, os comentários de abertura definem os tópicos da discussão e convidam os participantes a compartilhar suas observações iniciais, pensamentos e sentimentos. A colocação de normas comunica expectativas sociais e comportamentais a fim de aliviar a ansiedade de comunicação e possibilitar a participação. A colocação de uma agenda prepara os participantes a contribuir com comentários relevantes para a discussão. A função de referenciação ajuda a definir o contexto, a fornecer os materiais da discussão e a familiarizar os participantes com o background do tópico de discussão. Nessa fase, o reconhecimento também é essencial para dar suporte social aos participantes, de modo que se sintam acolhidos e suas contribuições iniciais sejam valorizadas. A avaliação também pode ser exercida nessa fase, a fim de juntar informações sobre a base de cada participante, sua preferência de ensino ou seu conhecimento prévio do assunto. Isso pode ser feito através de sondagens, pesquisas ou questionários online.

Uma série de funções são aplicáveis na fase de diálogo múltiplo. A referenciação, o reconhecimento, a solicitação, a avaliação e o metacomentário são frequentemente usados. O reconhecimento e a solicitação são provavelmente as funções mais exercidas. $O$ reconhecimento cumpre um papel social e comunicativo similar ao ato de atender alguém com uma mão levantada em sala de aula. A solicitação estimula o próximo passo ou a contribuição e também ajuda aqueles que aprendem a se moverem de uma a outra zona de desenvolvimento proximal. Essas duas funções frequentemente prosseguem lada a lado: o moderador primeiramente reconhece uma contribuição e solicita que o estudante avance um passo a mais. A avaliação nessa fase diagnostica más concepções e mede o progresso do aprendizado através de provas, exames ou sessões de revisão online. A tecitura é uma funçãochave desempenhada de vez em quando para fundamentar a comunicação e colocar ordem na discussão pela síntese das realizações do grupo.

A tecitura é a função mais importante desempenhada na última fase do discurso colaborativo engajado. Ela congrega os participantes na base comum estabelecida e constrói um consenso em torno das decisões e resoluções acerca dos tópicos da discussão. A avaliação é, nessa fase, frequentemente recapitulativa.

As duas metafunções - o metacomentário e a delegação - são úteis em toda parte. $\mathrm{O}$ metacomentário é requisitado sempre que existe uma ligação fraca na comunicação, ou alguma ameaça de ruptura devido a mal-entendidos, ou uma incerteza a respeito das normas.

\begin{tabular}{|c|c|c|c|c|}
\hline Q Rovista Dialectus & Ano 9 & n. 17 & Maio - Agosto 2020 & p.182-211 \\
\hline
\end{tabular}




\section{A PEDAGOGIA NO ESPACO CIBERNÉTICO: A DINÂMICA...}

Cindy Xin / Andrew Feenberg

Problemas comuns incluem a demora, o desvio do caminho, a falha em providenciar a evidência necessária do entendimento, o silêncio ou a exasperação. Além de consertar os problemas de comunicação, os metacomentários podem solicitar críticas e reclamações a fim de antecipar e resolver problemas antes que eles saiam do controle. A função de delegar é usada em qualquer estágio com a finalidade de designar estudantes para assumirem algumas das funções moderadoras. Os estudantes podem ser requisitados para escrever comentários que costuram o discurso, ou para introduzir sugestões de assunto, ou ainda subconferências podem ser criadas tendo estudantes como moderadores. Quando a execução de funções moderadoras é compartilhada entre os estudantes, as conversações tendem a ser mais engajadas e a resultar num aprendizado maior (XIN, 2002).

\section{Estudos adicionais}

Este artigo propõe um construto teórico da dinâmica de discurso colaborativo engajado nas conferências por computadores. Nosso objetivo é contribuir para um entendimento dessas práticas de professores e estudantes online, as quais são particularmente efetivas para a obtenção de objetivos pedagógicos, tais como o pensamento crítico e a mudança conceitual. Trabalhos futuros serão realizados em várias áreas.

Primeiro, o modelo em si precisa de maior elaboração e testagem. As ferramentas de análise para estudar e avaliar as conferências educacionais devem ser desenvolvidas.

Em segundo lugar, o robusto corpo da literatura em Análise do Discurso e os estudos iniciais sobre a conversa em sala de aula produziram insights valiosos sobre aprendizado e instrução. Precisamos aplicar mais esses insights às experiências educacionais online.

Em terceiro lugar, essa pesquisa tem sido realizada junto ao desenvolvimento e à testagem de novos projetos de programas de discussão online assíncrona (XIN; FEENBERG, 2002). O protótipo do programa TextWeaver está disponível no seguinte endereço eletrônico http://www.textweaver.org, e uma nova ferramenta, Marginalia, inspirada no TextWeaver, está disponível em http://www.geof.net/code/annotation. ${ }^{4}$ Esses projetos dão suporte às funções moderadoras e à interação a fim de melhorar a habilidade de trabalho conjunto online de

4 N. do T.: atualmente estão desativados esses endereços eletrônicos. Sobre o TextWeaver, cf.: https://sourceforge.net/projects/textweaver, sobre o Marginalia, cf.: http://webmarginalia.net.

\begin{tabular}{|c|c|c|c|c|}
\hline Q Rovista Dialectus & Ano 9 & n. 17 & Maio - Agosto 2020 & p.182-211 \\
\hline
\end{tabular}




\section{A PEDAGOGIA NO ESPACO CIBERNÉTICO: A DINÂMICA...}

Cindy Xin / Andrew Feenberg professores e estudantes. Estamos confiantes que trabalhos adicionais, teóricos e práticos, experimentarão um mútuo enriquecimento.

\section{Agradecimentos}

$\mathrm{O}$ artigo foi preparado a partir de uma bolsa do Fund for the Improvement of PostSecondary Education of the United States Department of Education. As visões aqui expressas são nossas e não necessariamente deles. O artigo se baseia no trabalho de Xin (2002). Nossos agradecimentos a Norm Friesen, Edward Hamilton e Peter Kandlbinder por suas proveitosas críticas a partir de um esboço inicial deste artigo. Ademais, agradecemos os editores e avaliadores do Journal of Distance Education, sediado no Canadá, por suas ideias e sugestões.

\section{Referências:}

ANDERSON, T.; ROURKE, L.; GARRISON, D. R.; ARCHER, W. (2001). Assessing teaching presence in a computer conferencing context. Journal of Asynchronous Learning Networks, vol. $5, \quad$ n. 2, pp. 1-17. Disponível em: https://olj.onlinelearningconsortium.org/index.php/olj/article/view/1875/706.

BERGE, Z. L. (1995). Facilitating computer conferencing: Recommendations from the field. Educational Technology, vol. 15, n. 1, pp. 22-30.

BRUFFEE, K. A. (1999). Collaborative learning: Higher education, interdependence, and the authority of knowledge ( $2^{\mathrm{a}}$ ed.). Baltimore, MD: Johns Hopkins University Press.

BURBULES, N. C. (1993). Dialogue in teaching: Theory and practice. New York, NY: Teachers College Press.

CLARK, H.; SCHAEFER, E. F. (1989). Contributing to discourse. Cognitive Science, vol. 13, n. 2, pp. 259-294. Disponível em: https://onlinelibrary.wiley.com/doi/pdf/10.1207/s15516709cog1302_7.

DEWEY, J. (1938). Experience and education. New York, NY: Touchstone.

FEENBERG, A. (1989). The written world. In: MASON, R.; KAYE, A. (Eds.). Mindweave: Communication, computers, and distance education. Oxford, UK: Pergamon Press, pp. 22-39.

FEENBERG, A. (2000). Online pedagogy with discussion management software. Texto apresentado na American Association of University Professors Annual Meeting, Washington, DC. 


\section{A PEDAGOGIA NO ESPACO CIBERNÉTICO: A DINÂMICA...}

Cindy Xin / Andrew Feenberg

FEENBERG, A.; XIN, M. C. (2002). A teacher's guide to moderating online discussion forums: From theory to practice. [S. l.: s. n.].

FEENBERG, A.; XIN, M. (2003). Facilitation. In: DISTEFANO, A. RUDESTARN, K. E.; SILVERMAN, R. (Eds.). Encyclopedia of distributed learning. Thousand Oaks, CA: SAGE Publications.

GADAMER, H.-G. (1982). Truth and method. New York, NY: Crossroads.

GARRISON, D. R. (1991). Critical thinking and adult education: A conceptual model for developing critical thinking in adult learners. International Journal of Lifelong Education, vol. 10 , n. 4 , pp. 287-303.

GARRISON, D. R.; ANDERSON, T.; ARCHER, W. (2001). Critical thinking, cognitive presence, and computer conferencing in distance education. American Journal of Distance Education, vol. 15, n. 1, pp. 7-23.

GARRISON, D. R.; ARCHER, W. (2000). A transaction perspective on teaching and learning: A framework for adult and higher education. Amsterdam: Pergamon.

GOFFMAN, E. (1961). Encounters. New York, NY: Bobbs-Merrill.

GOODWIN, C.; HERITAGE, J. (1990). Conversation analysis. Annual Review of Anthropology, vol. 19, pp. 283-307. Disponível em: https://www.annualreviews.org/doi/pdf/10.1146/annurev.an.19.100190.001435.

GUNAWARDENA, C. N. (1995). Social presence theory and implications for interaction and collaborative learning in computer conferences. Hsinchu, Taiwan. Texto apresentado na Fourth International Conference on Computer Assisted Instruction.

GUNAWARDENA, C. N.; ZITTLE, F. (1997). Social presence as a predictor of satisfaction within a computer mediated conferencing environment. American Journal of Distance Education, vol. 11, n. 3, pp. 8-26.

GUNAWARDENA, C. N.; LOWE, C. A.; ANDERSON, T. (1997). Analysis of a global online debate and the development of an interaction analysis model for examining social construction of knowledge in computer conferencing. Journal of Educational Computing Research, vol. 17, pp. 395-429.

HAMILTON, E.; FEENBERG, A. (no prelo). The technical codes of online education. Techné. Posteriormente publicado em: Techné, vol. 9, n. 1, pp. 97-123, outono de 2005 (N. do T.). Disponível em: https://www.sfu.ca/ andrewf/books/hamilton_feenberg_techne.pdf.

HERRING, S. (1996). Computer-mediated communication: Linguistic, social and crosscultural perspectives. Pragmatics and Beyond Series. Amsterdam: John Benjamin.

\begin{tabular}{|l|l|l|l|l|}
\hline Q & Anovita 9 & n. 17 & Maio - Agosto 2020 & p.182-211 \\
\hline
\end{tabular}




\section{A PEDAGOGIA NO ESPACO CIBERNÉTICO: A DINÂMICA...}

Cindy Xin / Andrew Feenberg

HERRING, S. (1999). Interactional coherence in CMC. Journal of Computer-Mediated Communication, $\quad$ vol. 4,4 n. 4 . 4 Disponível em: https://onlinelibrary.wiley.com/doi/full/10.1111/j.1083-6101.1999.tb00106.x.

HILTZ, S. R.; TUROFF, M. (1978). The network nation: Human communication via computer. Cambridge, MA: MIT Press.

HUTCHINS, E. (1991). The social organization of distributed cognition. In: RESNICK, L. S.; LEVINE, J. M.; TEASLEY, S. D. (Eds.). Perspectives on socially shared cognition. Washington, DC: American Psychology Association, pp. 283-307.

KANUKA, H. (2005). An exploration into facilitating higher levels of learning in a text-based internet learning environment using diverse instructional strategies. Journal of ComputerMediated Communication, vol. 10, n. 3. Disponível em: https://onlinelibrary.wiley.com/doi/full/10.1111/j.1083-6101.2005.tb00256.x.

KANUKA, H.; KREBER, C. (1999). Knowledge construction in the virtual classroom. Texto apresentado na 18th National Conference of the Canadian Association for the Study of Adult Education, Sherbrooke.

KITCHER, P. (1993). The advancement of science. New York, NY: Oxford University Press.

KOZULIN, A. (2003). Psychological tools and mediated learning. In: KOZULIN, A.; GINDIS, B.; AGEYEV, V. S.; MILLER, S. M. (Eds.). Vygotsky's educational theory in cultural context. New York, NY: Cambridge University Press, pp. 15-38.

LEVINSON, S.C. (1983). Pragmatics. New York, NY: Cambridge University Press.

LIPMAN, M. (1991). Thinking in education. Cambridge, UK: Cambridge University Press.

LYNCH, M. (1993). Scientific practice and ordinary action. Cambridge, UK: Cambridge University Press.

MAZUR, J. (2003). Conversation analysis for educational technologists: Theoretical and methodological issues for researching the structures, processes, and meaning of on-line talk. In: JONASSEN, D. H. (Ed.). Handbook of research for educational communications and technology: A project of the Association for Educational Communications and Technology. Mahwah, NJ: Erlbaum, pp. 1073-1098.

MERRILL, D. (1992). Constructivism and instructional design. In: DUFFY, T. M.; JONASSEN, D. H. (Eds.). Constructivism and the technology of instruction. Mahwah, NJ: Erlbaum, pp. 99-114.

NEWMAN, D. R.; JOHNSON, C.; COCHRANE, C.; WEBB, B. (1997). Evaluating the quality of learning in computer supported co-operative learning. Journal of American Society for Information Science, vol. 48, n. 6, pp. 484-495.

\begin{tabular}{|c|c|c|c|c|}
\hline Qonista Dialectus & Ano 9 & n. 17 & Maio - Agosto 2020 & p.182-211 \\
\hline
\end{tabular}


OATLEY, K. (1991). Distributed cognition. In: EYSENCK, H.; ELLIS, A.; HUNT, E.; JOHNSON-LAIRD, P. (Eds.). The Blackwell dictionary of cognitive psychology. Oxford, UK: Blackwell, pp. 102-107.

PEA, R. (1993). Practices of distributed intelligence and designs for education. In: SALOMON, G. (Ed.). Distributed cognitions: Psychological and educational considerations. Cambridge, UK: Cambridge University Press, pp. 47-87.

ROURKE, L. (2000). Operationalizing social presence in asynchronous, text-based computer conferencing. Texto apresentado na Canadian Association of Distance Education (CADE) annual conference, Quebec City.

ROURKE, L.; ANDERSON, T. GARRISON, D. R.; ARCHER, W. (1999). Assessing social presence in asynchronous, text-based computer conferencing. Journal of Distance Education, vol. 14, n. 2, pp. 51-70. Disponível em: https://auspace.athabascau.ca/handle/2149/732.

ROSCHELLE, J. (1996). Learning by collaborating: Convergent conceptual change. In: KOSCHMANN, N. J. M. T. (Ed.). CSCL: Theory and practice of an emerging paradigm. Mahwah, NJ: Erlbaum, pp. 209-248

ROSSMAN, M. (1999). Successful online teaching using an asynchronous learner discussion forum. Journal of Asynchronous Learning Networks, vol. 3, n. 2.

STALNAKER, R. C. (1978). Assertion. In: COLE, P. (Ed.). Syntax and semantics: Pragmatics. New York, NY: Academic Press, vol. 9, pp. 315-332.

VYGOTSKY, L. S. (1962). Thought and language. Cambridge, MA: MIT Press.

VYGOTSKY, L. S. (1978). Mind in society: The development of higher psychological processes. Cambridge, MA: Harvard University Press.

WOOD, D. (1999). Teaching the young child: Some relationships between social interaction, language and thought. In: LLOYD, P.; FERNYHOUGH, C. (Eds.). Lev Vygotsky: Critical assessments. London: Routledge, vol. 3, pp. 259-275.

XIN, M. C. (2002). Validity-centered design for the domain of engaged collaborative discourse in computer conferencing. Tese (de Doutorado). Provo, UT: Brigham Young University.

XIN, M. C.; FEENBERG, A. (2002). Designing for pedagogical effectiveness: TextWeaver. Texto apresentado na Hawaii International Conference of System Sciences, IEEE. 